\title{
Asthenospheric effect on the mantle substrate and diversity of kimberlite rocks in Zimni Bereg (Arkhangelsk province)
}

\author{
Sergey M. Sablukov and Liudmila I. Sablukova
}

RUSGEO Ltd, Moscow, Russia,

The Zimni Bereg diamond-bearing region of Russia is globally unique; it has two full Late Devonian kimberlite series (Al-series and Fe-Ti series) that are distinct in structure and composition, and differentiated from highly diamondiferous kimberlites to barren melilitites and picrites occurring together with basaltic volcanic pipes of the same age.

The Al-series rocks form a sequence (row) from diamondiferous kimberlites of the Zolotitsky pipe cluster (the Lomonosov deposit) to kimmelilitites and olivine melilitites of Verkhotina, Chidviya, Izhma and Suksoma. The Fe-Ti-series rocks form a row from diamondiferous kimberlites of the V. Grib deposit and poorly diamondiferous kimberlites of Pachuga to kimpicrites and melilite picrites of Shocha, Kepina, Soyana, Pachuga and Megra. The carbonatephlogopine picrites comprising the famous sill at the Mela River occupy a peculiar, "intermediate” position in the Zimni Bereg magmatic system, being just somewhat closer to Al-series kimberlites.

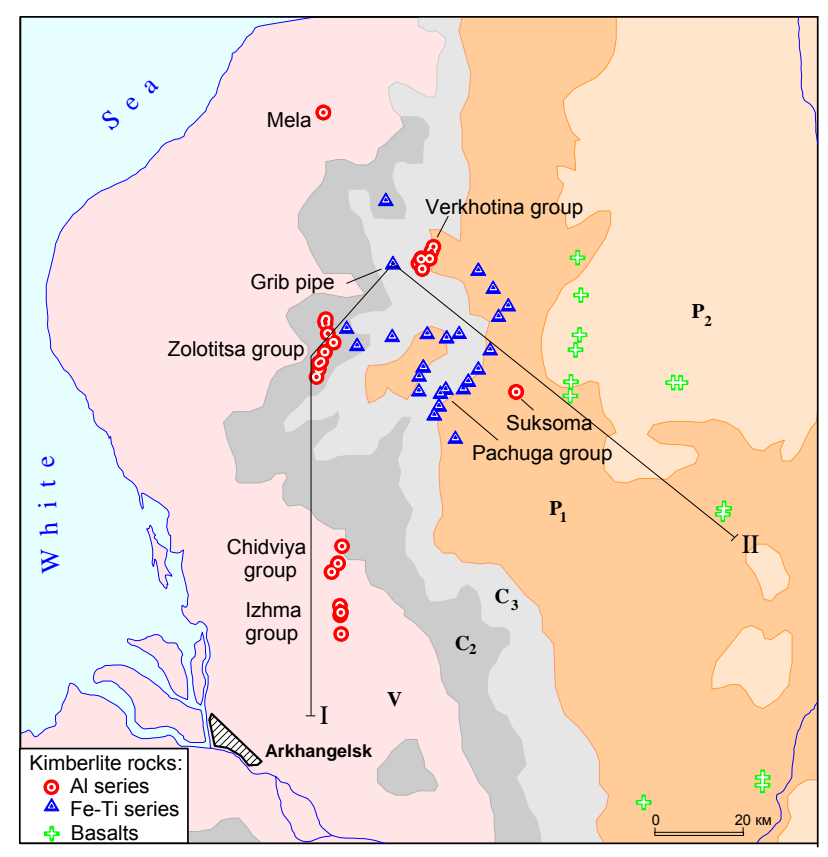

Distribution of volcanic rocks on the Zimny Bereg kimberlite area. I-II - line for model section of the upper mantle of the Zimni Bereg district.
A detailed study of 67 magmatic rock bodies located in the Zimni Bereg area was performed, including $\mathrm{Nd}-\mathrm{Sr}$ isotope dating for 30 rock bodies representing all local rock varieties.

To summarize, based on the most indicative isotopic and geochemical characteristics, the Fe-Ti-series kimberlitic rocks form a quite homogeneous group (regardless of their degree of ultramaficity), whereas the Al-series rocks are characterized by regular and intercorrelated variations in composition, including the $\mathrm{Ti}-\mathrm{Ta}-\mathrm{Sc}$ relationships and $\mathrm{Nd}-\mathrm{Sr}$ isotopic parameters.

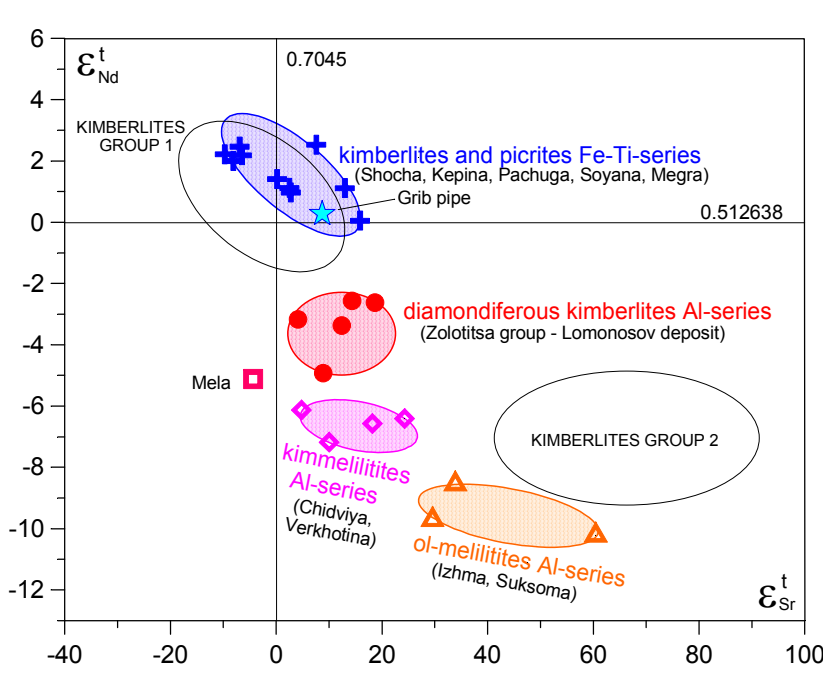

Sr and Nd isotopic compositions of the Zimni Bereg kimberlitic rocks (for a kimberlite age $370 \mathrm{Ma}$ ).

Analysis of the spatial distribution of kimberlitic rocks with dissimilar compositional characteristics in the Zimni Bereg area allows us to make certain inferences as to one of the factors probably responsible for the actual diversity of local kimberlites and their allied rocks.

The distribution of compositional characteristics of diversified kimberlite rocks in the study area is surprisingly regular, symmetric and consistent.

The Fe-Ti series kimberlite rocks (analogues to Group 1 kimberlites) located in the central part of the Zimni 
Bereg area show a set of mineralogical, geochemical and Nd-Sr characteristics suggesting an asthenospheric origin (Makhotkin et al., 1993) for these rocks (in particular, abundance of picroilmenite, high $\mathrm{TiO}_{2}$ (24.5 wt. \%), Ta (8-42 ppm), and $\mathrm{Nd}-\mathrm{Sr}$ isotope characteristics close to BSE parameters).

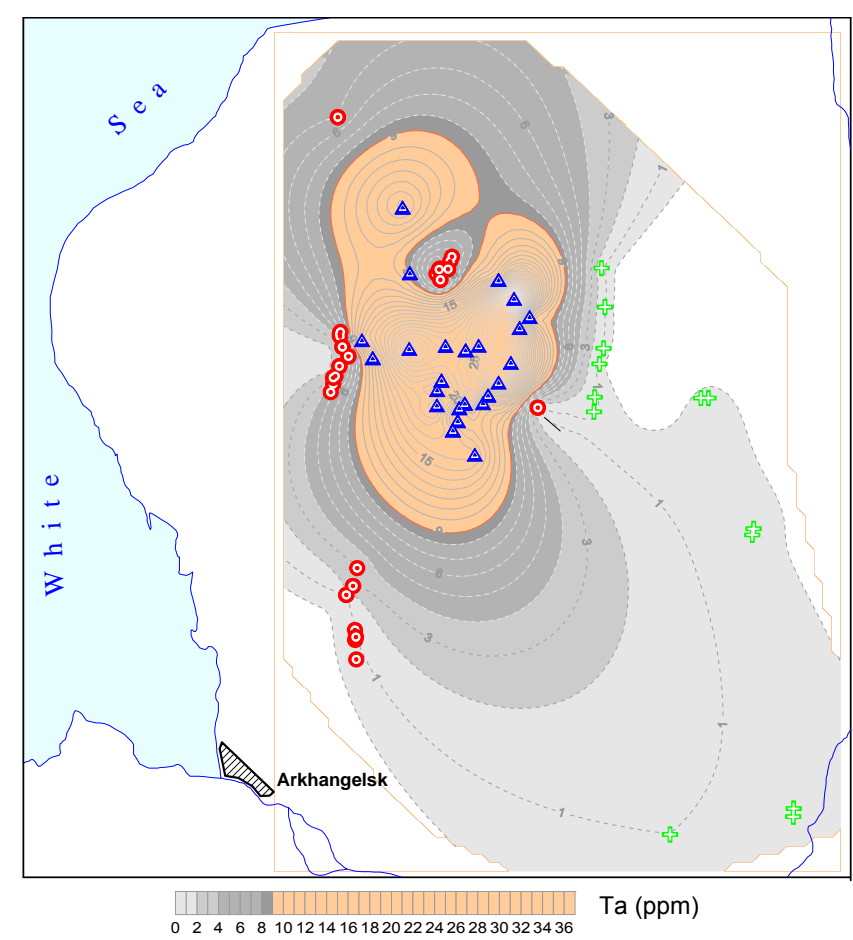

Isolines of Ta content (through $1 \mathrm{ppm}$ ) in the autoliths of the Zimni Bereg volcanic rocks.

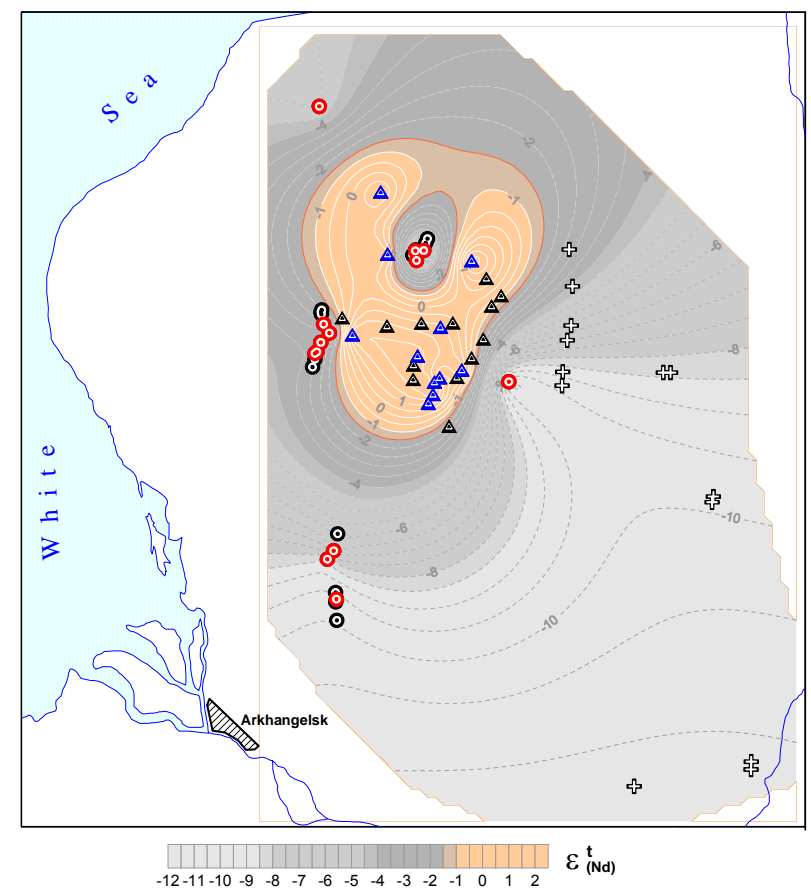

Isolines of $\varepsilon_{\mathrm{Nd}}^{\mathrm{t}}$ in the autoliths of the Zimni Bereg kimberlitic rocks.
The composition of Al-series kimberlite rocks (being somewhat similar to Group 2 kimberlites) shows a regular change from the marginal zones of the area towards its central part. In this direction, $\mathrm{TiO}_{2}$ content of the rocks increases from 0.15 to $1.59 \mathrm{wt}$ \%, their Ta content increases from 0.7 to $5.5 \mathrm{ppm}$, their $\mathrm{Nd}-\mathrm{Sr}$ isotope characteristics centripetally approach the BSE parameters, and the model age of mantle source enrichment relative to depleted mantle and chondrite reservoir is "rejuvenated", respectively, from 2110 to $1250 \mathrm{Ma}$ and from 1480 to $650 \mathrm{Ma}$. Along with this, according to paleofloristic (and scarce radiogeochronological) data, the age of intrusion is nearly the same for all the examined Zimni Bereg volcanic rock bodies, dated as $\mathrm{D}_{3}(360-374 \mathrm{Ma})$, which is generally close to the model age of mantle source enrichment relative to hondrite reservoir for $\mathrm{Fe}-\mathrm{Ti}$ series Zimni Bereg kimberlites $\left(\mathrm{T}_{\mathrm{Nd}}(\mathrm{CHUR})=309 \mathrm{Ma}\right.$ with $\left.\mathrm{T}_{\mathrm{Nd}}(\mathrm{DM})=850 \mathrm{Ma}\right)$.

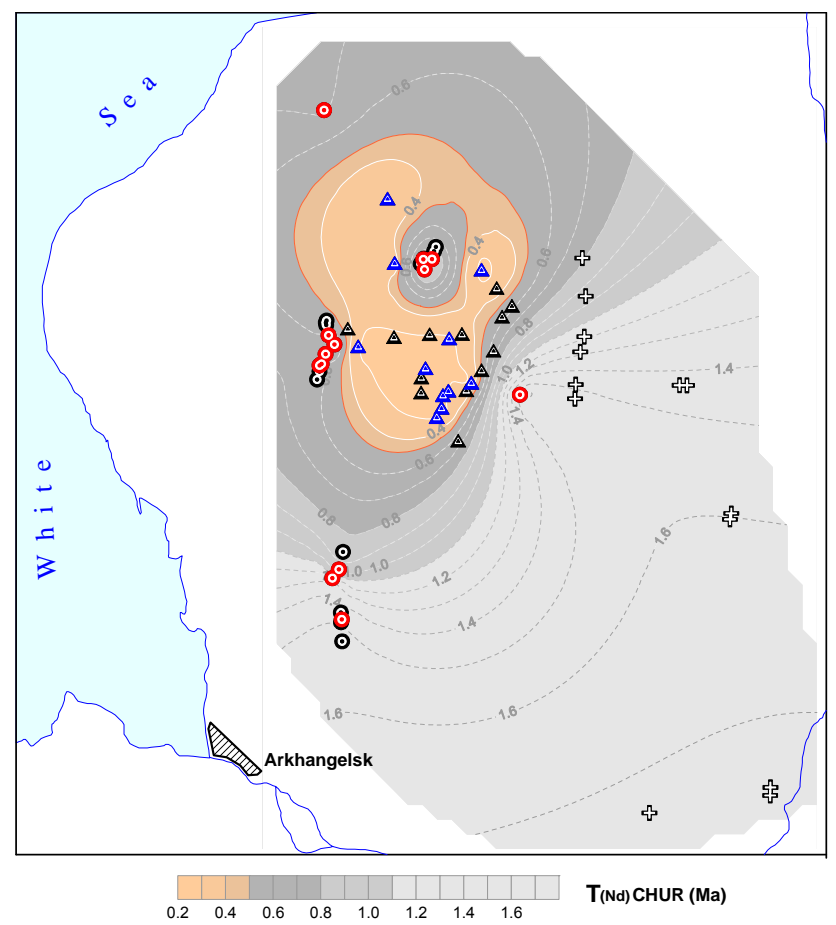

Isolines of $\mathrm{T}_{(\mathrm{ND})} \mathrm{CHUR}$ in the autoliths of the Zimni Bereg kimberlitic rocks.

For the Grib pipe, the age of kimberlite intrusion (paleofloristic data: $\mathrm{D}_{3}$; Rb-Sr: $373.1 \pm 5.1 \mathrm{Ma}$ ) is very close not only to model age of mantle source enrichment $\left(\mathrm{T}_{\mathrm{Nd}}(\mathrm{CHUR})=370 \mathrm{Ma}\right)$, lent also to the age of mantle clinopyroxene metasomatites (Rb-Sr: 372 and $385 \mathrm{Ma}$ ) and garnet-ilmenite clinopyroxenite from the "skarnoid" zone, i.e. zone of "hot" contact with garnet lherzolite (Rb-Sr: $361 \mathrm{Ma}$ ). In other words, enrichment of the mantle source with REE obviously proceeded nearly synchronously with the formation of ilmenite-containing rocks and potassic metasomatites of mantle substrate and intrusion of Grib pipe 
kimberlites, and these events and processes most likely were interrelated. Conceivably, the formation of the Grib pipe and other local Fe-Ti series kimberlites is related to intrusion of an asthenospheric diapir into the lithospheric mantle in the Middle to Late Devonian. This intrusion must have been quite local (several Tens of kilometers across) and probably, it had partially tectonic contacts, but, anyway, it was capable of forming vast zones of metasomatized (reworked to a variable extent) lithospheric mantle rocks around itself, from which the diversified local Al-series kimberlitic rocks could have originated. Gradual metasomatic transformation of mantle rocks, up to complete replacement of common garnet peridotite by garnetilmenite peridotite, is observed in mantle rock xenoliths of the V.Grib pipe.

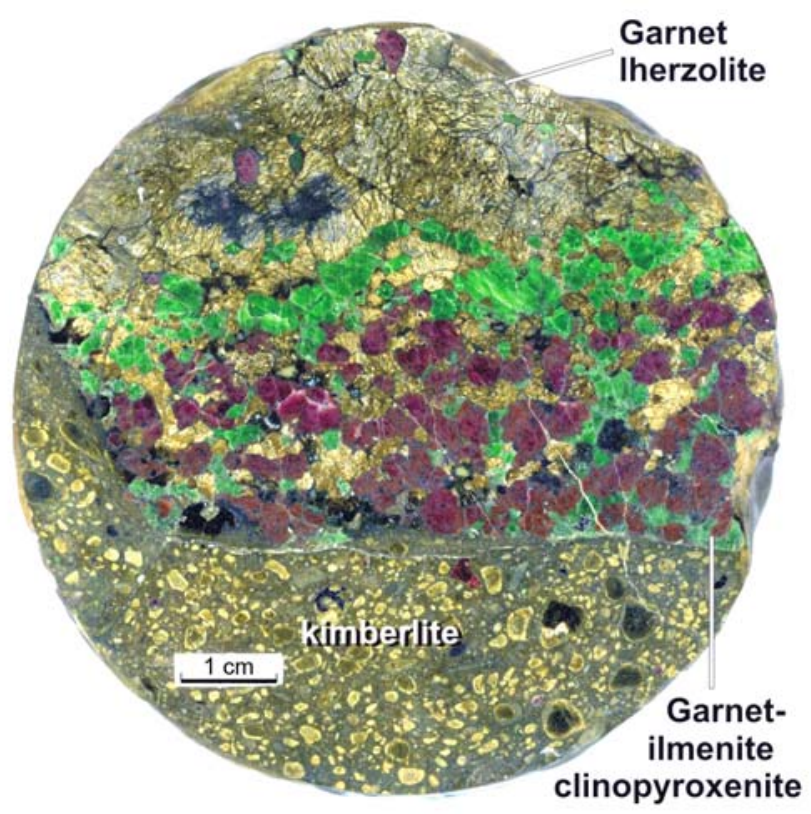

"Skarnoid" zone, i.e. zone of "hot" contact garnetilmenite clinopyroxenite with garnet lherzolite in the mantle xenoliths from the V. Grib kimberlite pipe.

The "centripetal rejuvenation" of model ages of mantle source enrichment for different Al-series kimberlite rocks in the study area may be related to gradual change in Nd isotope composition under the effect of a "young" asthenospheric diapir when passing away (outwards) from its boundary rather than to several non-synchronous enrichment events. The metasomatic "steaming" effect of an asthenospheric diapir on lithospheric mantle rocks could cause a change in their geochemical and isotope characteristics (the farther from the diapir boundary, the weaker the change), which inevitably reflected in certain change in geochemical and isotope characteristics of the kimberlites that formed as a result of their melting.

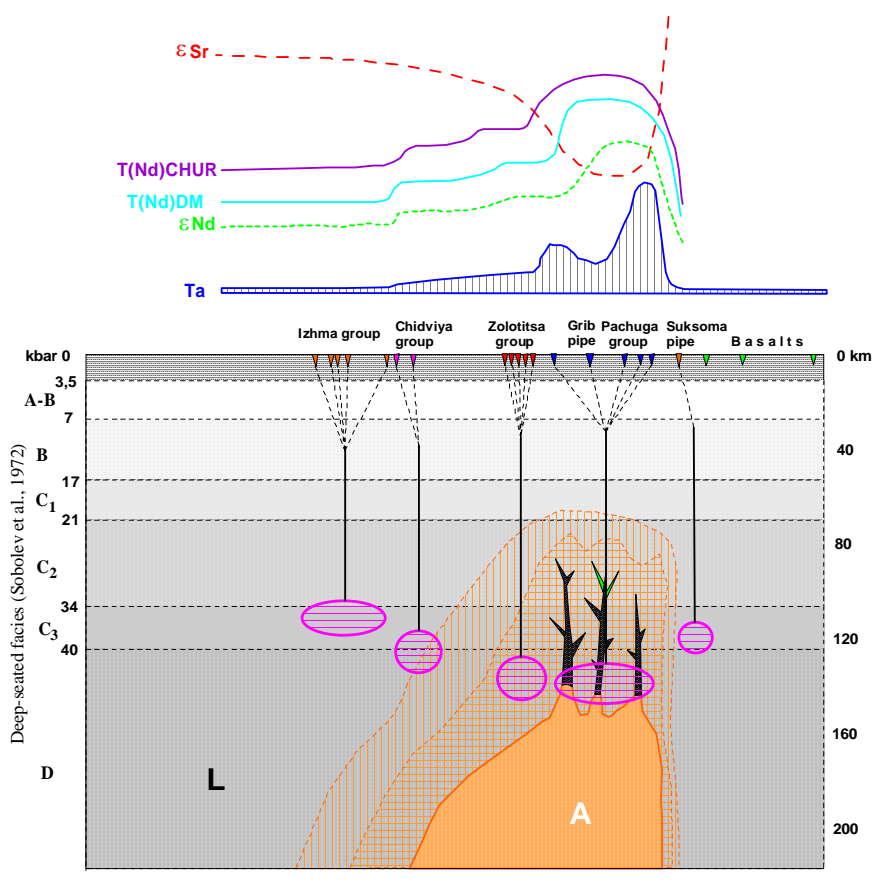

A model section on line I-II of the upper mantle of the Zimni Bereg district. A - asthenospheric intrusion, L lithospheric mantle. Different shading - zones with varying intensity of metasomatic working of lithospheric mantle rocks formed under the influence of an asthenospheric intrusion. Oval - the magma generation zones for different volcanic rock types. Above - character of change of isotopic-geochemical characteristics of volcanic rocks of the Zimni Bereg area on a line I-II.

The great diversity of kimberlitic rock varieties may be essentially due to heterogeneous structure of the mantle in the kimberlitic magma generation zone.

\section{References}

Makhotkin I.L. and Zhuravlev D.Z., 1993. Sr and Nd isotope composition of diamondiferous kimberlites and melilitites of the Arkhangelsk region .Dokl. Ross. Akad. Nauk, vol.332, no. 4, 491-495 (in Russian).

Sablukov S.M., 1990. Petrochemical series of the kimberlite rocks. Dokl. Akad. Nauk SSSR 313(4), 935-939 (in Russian).

Sablukov, S.M., Sablukova, L.I. and Shavirina, M.V., 2000. Mantle xenoliths in the Zimny Bereg kimberlite deposits of rounded diamonds, Arkhangelsk diamondiferous province. Petrologiya, 8(5), 466-494.

Sablukov, S.M., Sablukova, L.I. and Verichev, E.M., 2002. Essential types of mantle substrate in the Zimny Bereg region in connection with the formation of kimberlite hosting rounded and flat-faced diamonds. In: Proceedings of Int. Workshop "Deep-seated magmatism, magmatic sources and the problem of plumes”, Vladivostok, Russia, 185-202.

Sobolev, V.S, Dobretsov, N.L. and Sobolev, N.V., 1972. Classification of the deep-seated xenoliths and types of the upper mantle. Geol. and Geoph.12, 37-42. 